ISSN 1392-3196 / e-ISSN 2335-8947

Zemdirbyste-Agriculture, vol. 105, No. 1 (2018), p. 79-88

DOI 10.13080/z-a.2018.105.011

\title{
Ornamental potential and freezing tolerance of six Thymus spp. species as ground-covering plants in the landscape
}

\author{
Hassan Maleki LAJAYER ${ }^{1,2}$, Hedayat ZAKIZADEH ${ }^{1}$, Yousef HAMIDOGHLI ${ }^{1}$, \\ Mohammad Hassan BIGLUEI ${ }^{1}$, Esmaeil CHAMANI ${ }^{2}$ \\ ${ }^{1}$ University of Guilan \\ Rasht, Iran \\ E-mail: hamidoghli@guilan.ac.ir \\ ${ }^{2}$ University of Mohaghegh Ardabili \\ Ardabil, Iran
}

\begin{abstract}
The current study looks at the possibility of using three native (Thymus kotschyanus Boiss. and Hohen, T. fedtschenkoi Ronniger and T. pubescence Boiss \& Kotschy ex Celak), one endemic (T. daenensis Jalas) and two common (T. serpyllum L. and T. vulgaris L.) thyme (Thymus spp.) species as ground-covering plants in landscaping. The ornamental potential and freezing tolerance of the species were examined over a period of two years from 2014 to 2016. T. kotschyanus indicated some important ornamental characteristics, including early flowering habit, long flowering period, more inflorescences per plant, larger flowers, relatively high area coverage and a higher ranking in visual assessment. In contrast, T. serpyllum was observed to have more flowers per inflorescence, more and long inflorescences, high visual assessment ranking and area coverage. The survival rates of the plants put under freezing chamber conditions at $-10^{\circ} \mathrm{C}$ and $-30^{\circ} \mathrm{C}$ were $100 \%$ and $0 \%$, respectively, while at $-20^{\circ} \mathrm{C}$ the highest survival rates were observed only in T. vulgaris and T. serpyllum. Moreover, all species had $100 \%$ survival rate in harsh winter conditions of Ardabil Province, Iran. The results of electrolyte leakage measurements demonstrated that among all species, T. serpyllum, T. kotschyanus and T. vulgaris had the highest level of hardiness against the cold. The highest proline contents were also observed in T. vulgaris and T. kotschyanus, respectively. The activity of peroxidase antioxidant enzyme in T. vulgaris and T. serpyllum did not change in response to freezing stress. However, it decreased in T. kotschyanus by increasing the stress severity. No significant difference was observed in the superoxide dismutase and ascorbate peroxidase enzyme activities of the species. Overall, all the examined species showed valuable ornamental characteristics and freezing stress tolerance. However, only T. kotschyanus, T. serpyllum and T. vulgaris were suggested to be used for landscaping programs.
\end{abstract}

Key words: electrolyte leakage, flower number, flowering period, native plants, peroxidase, thyme.

\section{Introduction}

The planting and maintenance of plants in urban landscapes are very expensive. Therefore, having the policy to use plants that are cheaper to grow and more adaptable to local conditions, it is vital to decrease the expenses of large-scale practices. Plants are a source of human distress in urban areas if they are not selected well (Asgarzadeh et al., 2014). There are some factors influencing plant selection for landscaping programs, which include assessments of hardiness and aesthetics, ease of propagation and culture, naturalisation potential. Roloff et al. (2009) considered drought tolerance and winter robustness as decisive criteria for selecting tree species for urban habitats considering climate change. Freezing stress often limits the distribution of many plant species. It is well-documented that there is an intra-specific variation in the cold sensitivity of many plants (Cavender-Bares, 2007). During a period of low but non-freezing temperatures in a process called coldacclimation plants can increase their ability to withstand freezing temperatures (Livingston et al., 2006). Cold acclimation is a complex process associated with physiological and biochemical changes in the plants, including modifications in membrane lipid composition, increases in soluble sugars and amino acids, synthesis and accumulation of antioxidants enzymes and changes in hormone levels (Hao et al, 2009). There are a lot of studies on screening for freezing tolerance of plant species in recent years: Stenotaphrum secundatum

Please use the following format when citing the article:

Lajayer H. M., Zakizadeh H., Hamidoghli Y., Bigluei M. H., Chamani E. 2018. Ornamental potential and freezing tolerance of six Thymusspp. species as ground-covering plants in the landscape. Zemdirbyste-Agriculture, 105 (1): 79-88 DOI 10.13080/z-a.2018.105.0011 
(Li et al., 2010), Triticum aestivum (Armoniené et al., 2013), blueberry (Rowland, Ogden, 2013), Paspalum vaginatum (Fabbri et al., 2015).

Besides having good stress tolerance, species introduced to landscape should have good ornamental characteristics. There is a growing demand for native plants in the landscape and the use of native plants by landscape designers has increased in recent years (Brzuszek et al., 2007). Moreover, these plants are the foundation for the local ecosystem, because they provide habitat and food for wildlife (Tallamy, 2007). Assessing the potential of native useful plants needs to be prioritized since they are still very poorly known and their potential is still insufficiently exploited (Mugge et al., 2016). There are lots of works on the possibility of using native and medicinal plants in landscaping, such as chamomile species (Ghani et al., 2011), Sedum spurium and Thymus paraecox (Acar, Var, 2001), Ajuga reptans (Foo et al., 2009). The performance of one turfgrass (Poa pratensis L. 'Apollo') and eight landscape species (Achillea millifolium, Ajuga reptans 'Bronze Beauty', Liriope muscari (Decne.), Pachysandra terminalis Siebold, Sedum album, Thymus serpyllum, Vinca major and $V$. minor) were studied during a severe drought and subsequent recovery. The results have shown that S. album, L. muscari and P. terminalis performed best (Domenghini, 2012).

The genus Thymus L. belongs to the Lamiaceae family, consisting of about 215 species of herbaceous perennials and small shrubs in the world. They are native to Mediterranean region, from which 14 species exist in Iran flora. These species include T. daenensis Jalas, T. carmanicus Jalas, T. fallax Fisch \& C.A.
Mey, T. persicus, T. trautvetteri Klokov \& Desj-shost, T. migricus Klokov \& Desj-shost., T. kotschyanus Boiss. \& Hohem, T. pubescence Boiss \& Kotschy ex Celak, T. nummularius M.B., T. transcaspicus Klokov, $T$. eriocalyx (Ronniger) Jalas, T. causcasicus wild ex Ronniger subsp. grossheimii (Ronniger) Jalas, T. transcaucasicus Klokov and T. fedtschenkoi Ronniger (Pirbaluti et al., 2015). The aim of these studies was to investigate the possibility of using three native, one endemic and two commonly used Thymus species in the landscape by evaluating their freezing tolerance and ornamental potential.

\section{Materials and methods}

Plant material. Six thyme (Thymus L.) species, including T. kotschyanus Boiss. and Hohen, T.fedtschenkoi Ronniger, T. pubescence Boiss \& Kotschy ex Celak, T. daenensis Jalas, T. serpyllum L. and T. vulgaris L., were used in the present study. The seeds of the species were purchased from Research and Education Centre of Agriculture and Natural Resources Organization in East Azarbaijan Province, Iran.

Evaluation of ornamental potentials. This experiment was carried out at the experimental station of the College of Agriculture and Natural Resources, University of Mohaghegh Ardabili, Ardabil, Iran over a period of two years (2014 to 2016). Annual rainfall in Ardabil Province is about $290 \mathrm{~mm}$ and precipitation falls in winter as snow and rainfall mainly occurs between November and May. The number of freezing days in winter months is often more than 15 days per month. The absolute and average minimum temperatures during the experiment are shown in Table 1.

Table 1. Meteorological data of cold months at Ardabil Weather Station, Iran

\begin{tabular}{|c|c|c|c|c|}
\hline Month & Year & $\begin{array}{c}\text { Freezing } \\
\text { days } \\
\text { No. }\end{array}$ & $\begin{array}{c}\text { Absolute } \\
\text { minimum temperature } \\
{ }^{\circ} \mathrm{C}\end{array}$ & $\begin{array}{c}\text { Average } \\
\text { minimum temperature } \\
{ }^{\circ} \mathrm{C}\end{array}$ \\
\hline \multirow{2}{*}{ November } & 2014 & 18 & -5.8 & 0.1 \\
\hline & 2015 & 22 & -10 & -2.2 \\
\hline \multirow{2}{*}{ December } & 2014 & 18 & -13.8 & -2.4 \\
\hline & 2015 & 21 & -11 & -1.6 \\
\hline \multirow{2}{*}{ January } & 2015 & 21 & -8.8 & -1.6 \\
\hline & 2016 & 26 & -16 & -4.8 \\
\hline \multirow{2}{*}{ February } & 2015 & 26 & -18.8 & -5.1 \\
\hline & 2016 & 14 & -13.2 & 0.2 \\
\hline
\end{tabular}

The field's soil is of sandy-loam type with a $\mathrm{pH}$ of 7.8. NPK fertilizer at rates (in pure elements) of 90-60-90 $\mathrm{kg} \mathrm{ha}^{-1}$ were used before sowing. Weeds were controlled by hand and no pesticides were applied during the plant growing season. Several plots measuring $1.5 \times$ $1.5 \mathrm{~m}$ were prepared for planting and then separated by $100 \mathrm{~cm}$ borders. Firstly, the seeds germinated in containers filled with sand/soil/decomposed cow manure substrate $(1: 1: 1 \mathrm{v} / \mathrm{v})$ in greenhouse conditions; the seedlings were then transferred from containers to the plots in early April. Morphological properties (leaf and flower size, inflorescence and flower number, diameter and length, plant height and area coverage), phenological properties (flowering period and the onset of flowering) and visual assessment (ranking) of the species were recorded during the growing seasons. This experiment was conducted in a completely randomized block design with 8 replications for each species (plots with six plants).

Laboratory and field experiment for evaluation of freezing stress tolerance. In order to evaluate the freezing tolerance, the seedlings germinated under greenhouse conditions were transferred to the outdoor conditions until 
late November to acclimatize naturally (the average mean temperature over the period of three years from 2014 to 2016 was $6.1-7.6^{\circ} \mathrm{C}$ ). Twenty-four hours before the end of the acclimation period, the plants (in their containers) were irrigated and transferred to a freezing chamber with $3^{\circ} \mathrm{C}$ temperature for subsequent exposure to freezing temperatures $\left(-10,-20\right.$ and $\left.-30{ }^{\circ} \mathrm{C}\right)$. The temperature was reduced at the rate of $2^{\circ} \mathrm{C}$ per $h$. After being exposed to the freezing temperature for $1 \mathrm{~h}$, the plants were transferred to a growth chamber with $4^{\circ} \mathrm{C}$ temperature for $24 \mathrm{~h}$ to reduce the ice melting speed and then were returned to the glasshouse. There were 10 plants in each container as well as four containers for each species. Proline content, electrolyte leakage (EL), peroxidase (POD), superoxide dismutase (SOD) and ascorbate peroxidase (APX) enzymes activity of the species were measured immediately. Their survival rate, however, was evaluated after being kept under greenhouse conditions for 30 days. Moreover, winter survival rates of the species under field conditions were recorded and calculated in early April, when most of the plant species start to grow in the region.

Leaf size and area coverage. The area coverage and leaf size were measured by software Image $J$ (Chaudhary et al., 2012). For this purpose, photos of the plants surrounded by a frame with a known area were taken by a digital camera from above. The photos were then penned in the software and the both the frame and plant areas were selected by selection tools and measured in pixels. Since the actual area of the frame was known, the area of the plant was calculated relative to the frame area.

Visual assessment. For visual assessment of species in both vegetative and reproductive stages over two years, the participants (about $20 \mathrm{PhD}$ and $\mathrm{MSc}$ horticultural students) were asked to rank the beauty of species from 1 (the worst) to 6 (the best) (Ghani et al., 2011). The data were analysed based on non-parametric Freidman test. There were a total of 48 plants for each species ( 8 plots each containing 6 plants).

Morphological and phenological properties. The onset of the flowering was calculated from the time the seedlings were transplanted to the field until the time $50 \%$ of the plants in each plot produced flower. The flowering period was also calculated from the beginning of the flowers to the abscission of almost all flowers. Flower size and diameter, plant height, and inflorescence length were measured with a ruler. Moreover, two plants in each block were selected and inflorescences per plant and flower per inflorescence were counted precisely.

Determination of survival rate. The survival rate was determined by counting alive plants remaining within each container under freezing chamber conditions four weeks after the return of the plants to the greenhouse. Moreover, for calculating the survival rates under the outdoor conditions, the alive plants were counted in early spring each year. Survival rate was calculated based on the following formula:

$$
\text { Survival rate }(\%)=\frac{\mathrm{N}}{\mathrm{N}_{0}} \times 100 \text {, }
$$

where $\mathrm{N}$ is the number of alive plants after freezing stress, $\mathrm{N}_{0}$ - the number of alive plants before freezing stress.
Enzyme essay. Thyme leaves $(0.25 \mathrm{~g})$ were homogenized in $1 \mathrm{~mL}$ of $50 \mathrm{mM}$ potassium phosphate buffer ( $\mathrm{pH}$ 7.0) containing $1 \mathrm{mM}$ of ethylenediaminetetraacetic acid (EDTA) at the presence of polyvinyl pyrrolidone (PVP).

The homogenate was centrifuged at $15000 \mathrm{~g}$ for $15 \mathrm{~min}$ at $4^{\circ} \mathrm{C}$. The supernatant was used to measure the activities of SOD, POD and APX. All assays were done at $25^{\circ} \mathrm{C}$ using a spectrophotometer Genway 6705 (Genway Biotech, USA). POD activity was determined at $470 \mathrm{~nm}$ by its ability to convert guaiacol to tetraguaiacol $\left(\varepsilon=26.6 \mathrm{mM}^{-1} \mathrm{~cm}^{-1}\right)$ (In etal., 2007). The reaction mixture contained $1485 \mathrm{ml}$ of guaiacol (112 $\mu$ l guaiacol in $20 \mathrm{ml} \mathrm{K-phosphate} \mathrm{buffer),} 1485 \mathrm{ml}$ hydrogen peroxide $\left(450 \mu \mathrm{H}_{2} \mathrm{O}_{2}\right.$ in $20 \mathrm{ml} \mathrm{K}$-phosphate buffer) and $30 \mathrm{ml}$ enzyme extract. An increase in absorbance was noticed by adding $\mathrm{H}_{2} \mathrm{O}_{2}$ at $470 \mathrm{~nm}$ for $1 \mathrm{~min}$. SOD activity was measured based on the method introduced by Giannopolitis and Ries (1977) in terms of the ability to inhibit the photochemical induction of nitroblue tetrazolium (NBT) to formazan at $560 \mathrm{~nm}$. The amount of reduced NBT was calculated using the absorbance coefficient $100 \mathrm{mM}^{-1} \mathrm{~cm}^{-1}$. One unit of SOD, defined as the amount required to inhibit the reduction of NBT up to $50 \%$, was recorded at $560 \mathrm{~nm}$. In order to estimate the APX activity, $0.1 \mathrm{ml}$ of enzyme extract was added to $2.8 \mathrm{ml}$ reaction mixture composed of $0.5 \mathrm{mM}$ ascorbic acid in $50 \mathrm{~m} M$ phosphate buffer ( $\mathrm{pH} 7.0$ ). $\mathrm{H}_{2} \mathrm{O}_{2}$-dependent oxidation of ascorbate was followed by a decrease in the absorbance at $290 \mathrm{~nm}$ after the addition of $0.1 \mathrm{ml} \mathrm{H}_{2} \mathrm{O}_{2}$ (Nakano, Asada, 1984).

Estimation of proline. The proline was estimated based on the method of Bates et al. (1973). The absorbance level of chromospheres was taken at $520 \mathrm{~nm}$. Proline concentration was estimated using the standard curve prepared from L-proline $\left(0-100 \mu \mathrm{g} \mathrm{ml}^{-1}\right)$.

Electrolyte leakage. For this purpose, 20 mature leaves were thoroughly rinsed three times with deionized water to remove electrolytes adhering to the leaf surface. After the final rinsing, all the leaves-containing test tubes were filled with $10 \mathrm{ml}$ of deionized water and capped with aluminium foil to prevent evaporation. They were kept at room temperature $\left(25^{\circ} \mathrm{C}\right)$. After incubation, the electrical conductance $\left(\mathrm{EC}_{1}\right)$ of the samples was initially measured by an electrical conductivity meter at room temperature. The tubes were then autoclaved at $0.1 \mathrm{Mpa}$ for $20 \mathrm{~min}$ to kill the tissues completely and release all the electrolytes (Al Busaidi, Farag, 2015). Finally, they were cooled to $25^{\circ} \mathrm{C}$ and the final conductance $\left(\mathrm{EC}_{2}\right)$ was measured. The electrolyte leakage (EL) was calculated as follows:

$$
\mathrm{EL}(\%)=\left(\mathrm{EC}_{1} / \mathrm{EC}_{2}\right) \times 100 \text {. }
$$

Statistical analysis. The analysis of variance was performed using software SAS 9.2 and SPSS 16.0. Mean values for different species were compared via Duncan multiple tests. The significance level was set as $P \leq 0.05$ in all analyses. 


\section{Results and discussion}

Evaluation of ornamental potential. The analysis of variance of the data showed a significant difference among thyme species in all examined parameters. Moreover, such criteria as the plant height, flower number, onset of flowering, flowering period and plant area coverage both in vegetative and reproductive stages in two following years were statistically different $(P \leq 0.05)$.

Visual assessment. The analysis of variance of Freidman's test with ranking showed that the acceptance level of Thymus species among the contributors was statistically different $(P \leq 0.05)$ in both vegetative and reproductive stages. In full bloom stage, the acceptance rates of T. serpyllum, T. kotschyanus, T. fedtschenkoi, T. vulgaris, $T$. daenensis and $T$. pubescence were 5.36, 4.92, 3.56, 3.33, 2.19 and 1.64, respectively. In the vegetative stage, the highest scores were given to T. serpyllum and T. kotschyanus (5.29 and 4.47), while the lowest ranks were devoted to $T$. pubescence and T. daenensis (Figs 1 and 2).

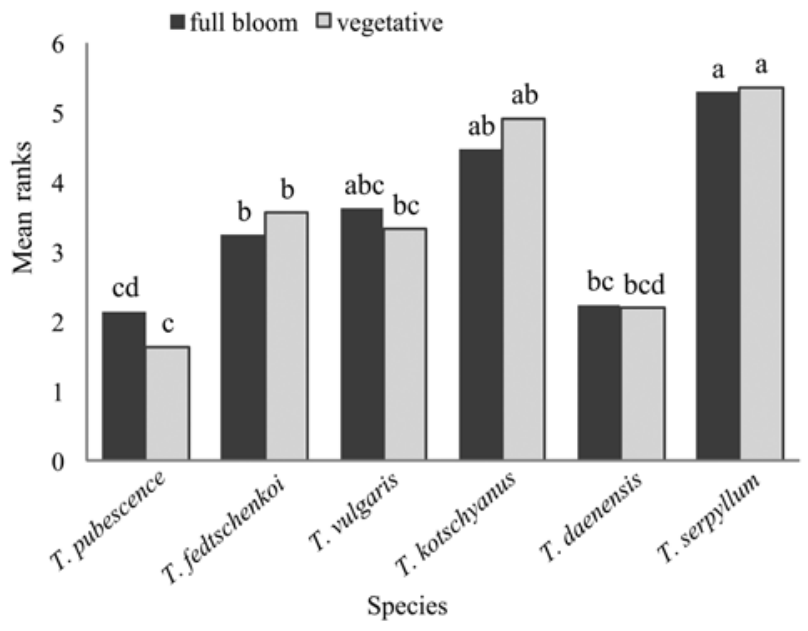

Note. Different letters indicate statistically significant differences $(P<0.05)$ between the species.

Figure 1. Comparison of Thymus species ornamental potential in the full bloom and vegetative stages by Freidman's test with ranking


Figure 2. Species of Thymus kotschyanus (A), T. serpyllum (B), T. fedtschenkoi (C), T. vulgaris (D), T. daenensis (E) and T. pubescence $(\mathrm{F})$

Reproductive and vegetative parameters. The required time for the flowering of different species of Thymus varied between 40 to 80 days. T. kotschyanus started to flower about 40 days after being planted in outdoor conditions, whereas T. serpyllum needed about 80 days. Those species with early flowering habit due to favourable weather conditions in early spring also had the longest flowering period. In the second year, T. kotschyanus flowered twice in spring. The longest
(72 days) and the shortest (37 days) flowering periods were recorded for $T$. kotschyanus and $T$. daenensis, respectively. However, all six species showed a long flowering period (Fig. 3A). T. serpyllum had the highest inflorescence number per plant (237) and flower number per inflorescence (158). There were more flowers per inflorescence in T. serpyllum, T. daenensis and T. vulgaris, compared to other species (Fig. 3B). 

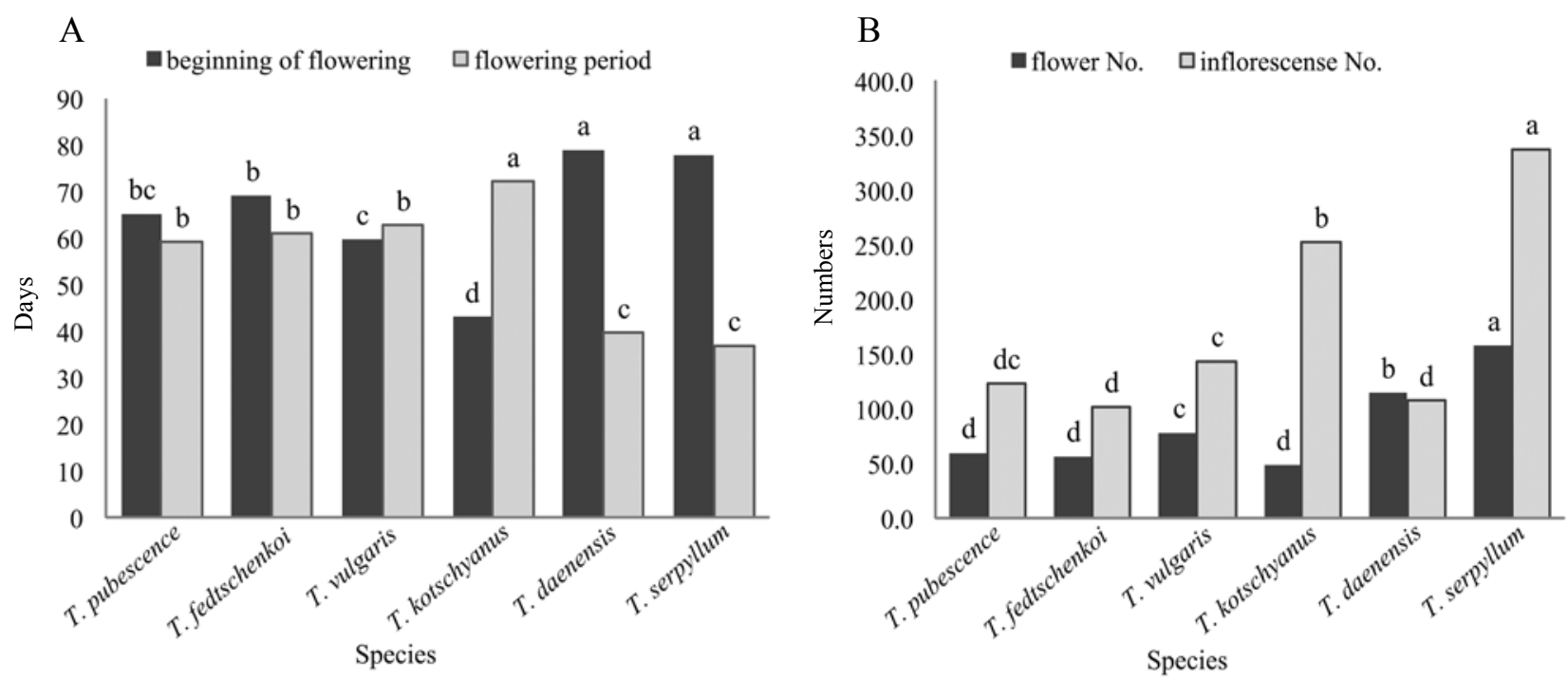

Explanation under Figure 1

Figure 3. Mean comparison of flowering period, beginning of flowering (A), inflorescence and flower numbers per inflorescence (B) in Thymus species

The longest inflorescences (92 and $90 \mathrm{~mm}$, respectively) belonged to $T$. vulgaris and $T$. serpyllum, and the species with more flowers had smaller flowers, except for $T$. daenensis. In contrast, $T$. serpyllum and T. vulgaris with more flowers per inflorescence had the smallest flowers $(2.86$ and $3.56 \mathrm{~mm}$, respectively). The flowers of T. daenensis, T. kotschyanus and T. fedtschenkoi were about twice as large as those of T. serpyllum. Due to larger flowers, the inflorescence diameter of $T$. daenensis, T. fedtschenkoi and T. kotschyanus was larger than that of other species which owned showy flowers (Table 2).

Table 2. Mean comparison of traits in different Thymus species during a two year experiment

\begin{tabular}{lcccccc}
\hline \multicolumn{1}{c}{ Species } & $\begin{array}{c}\text { Inflorescence length } \\
\mathrm{mm}\end{array}$ & $\begin{array}{c}\text { Inflorescence diameter } \\
\mathrm{mm}\end{array}$ & $\begin{array}{c}\text { Flower size } \\
\mathrm{mm}\end{array}$ & $\begin{array}{c}\text { Leaf size } \\
\mathrm{cm}^{2}\end{array}$ & $\begin{array}{c}\text { Plant height } \\
\mathrm{cm}\end{array}$ & $\begin{array}{c}\text { Area coverage } \\
\mathrm{cm}^{2}\end{array}$ \\
\hline T. pubescence & $36.8 \mathrm{~b}$ & $26.6 \mathrm{a}$ & $5.38 \mathrm{c}$ & $0.28 \mathrm{c}$ & $10.2 \mathrm{c}$ & $875.5 \mathrm{c}$ \\
T. fedtschenkoi & $32 \mathrm{~b}$ & $22.8 \mathrm{c}$ & $6.12 \mathrm{ab}$ & $0.37 \mathrm{~b}$ & $13.8 \mathrm{~b}$ & $647 \mathrm{c}$ \\
T. vulgaris & $92 \mathrm{a}$ & $14.42 \mathrm{e}$ & $3.56 \mathrm{~d}$ & $0.05 \mathrm{e}$ & $20.6 \mathrm{a}$ & $1299 \mathrm{~b}$ \\
T. kotschyanus & $22.9 \mathrm{c}$ & $23.97 \mathrm{bc}$ & $5.66 \mathrm{bc}$ & $0.25 \mathrm{~d}$ & $10.6 \mathrm{c}$ & $1300 \mathrm{~b}$ \\
T. daenensis & $35.5 \mathrm{~b}$ & $24.8 \mathrm{ab}$ & $6.5 \mathrm{a}$ & $0.4 \mathrm{a}$ & $15 \mathrm{~b}$ & $1188 \mathrm{~b}$ \\
T. serpyllum & $90.5 \mathrm{a}$ & $20 \mathrm{~d}$ & $2.87 \mathrm{~d}$ & $0.22 \mathrm{~d}$ & $13.8 \mathrm{~b}$ & $2306 \mathrm{a}$ \\
\hline
\end{tabular}

Note. Different letters in columns denote significant differences (Duncan test, $p<0.05$ ).

The area coverage, which represents the growth habit and rate of the species, of $T$. serpyllum was about two times bigger than that of $T$. pubescence and T. fedtschenkoi, which is indicative of its high growth rate and creeping growth habit. The area coverages of T. kotschyanus, T. vulgaris and T. daenensis were not statistically different; meanwhile, they indicated relatively high growth rate and area coverage. Like the flower's size, size of the leaves in T. daenensis and T. fedtschenkoi were larger than other species. As shown in Table 2, the smallest leaves were measured in $T$. vulgaris $\left(0.05 \mathrm{~cm}^{2}\right)$ which, nevertheless, were really persistent under hot and dry conditions. Additionally, colour of the leaves in $T$. vulgaris was different from other species, which might be a good combination with other species for planting design. Due to upright-growing habit, the plant height in T. vulgaris was higher than that of other species. Unlike that, the plant height in $T$. daenensis during the vegetative stage was relatively low because of the rosette growing habit. But during the reproductive stage, this species produced a long flowering stalk. In general, the plant height of all six species was really low, but different growth habits were observed among the species.

The performances of Thymus species in two following years. Onset of the flowering and flowering period were considerably affected by environmental conditions in two experimental years. Due to high adaptation to environmental conditions in the second year of the experiment, the species started to flower 30 days earlier than in the first year. This could also be due to late transplantation of the species from greenhouse to the outdoor conditions (because of extreme weather condition) in the first year (Table 3). As the result, the flowering time of the species coincided with hot summer weather that made a 12-day reduction in the flowering period. The area covered with the plants in the second year was much bigger than in the first year. These results can probably be attributed to higher efficiency of water 
Table 3. The performance of Thymus species during the two experimental years

\begin{tabular}{cccccccc}
\hline Year & $\begin{array}{c}\text { Flowering } \\
\text { period }\end{array}$ & $\begin{array}{c}\text { Beginning of } \\
\text { flowering }\end{array}$ & $\begin{array}{c}\text { Flower } \\
\text { number }\end{array}$ & $\begin{array}{c}\text { Inflorescence } \\
\text { number }\end{array}$ & $\begin{array}{c}\text { Leaf size } \\
\mathrm{cm}^{2}\end{array}$ & $\begin{array}{c}\text { Height } \\
\mathrm{cm}\end{array}$ & $\begin{array}{c}\text { Area coverage } \\
\mathrm{cm}^{2}\end{array}$ \\
\hline 2015 & $49.5 \mathrm{~b}$ & $51.2 \mathrm{~b}$ & $70.5 \mathrm{~b}$ & $158.7 \mathrm{a}$ & $0.25 \mathrm{a}$ & $12.1 \mathrm{~b}$ & $517.5 \mathrm{~b}$ \\
2016 & $61 \mathrm{a}$ & $80.4 \mathrm{a}$ & $94 \mathrm{a}$ & $178.2 \mathrm{a}$ & $0.28 \mathrm{a}$ & $16 \mathrm{a}$ & $3614.7 \mathrm{a}$ \\
\hline
\end{tabular}

Note. Different letters in columns denote significant differences (Duncan test, $p<0.05$ ).

use in the second year as well as more developed root system and perennial growth habit of the species. It was reported that the onset of flowering and flowering period of T. kotschyanus were influenced by environmental conditions in different years (Moradi et al., 2014). Khazaie et al. (2008) also reported that Thymus vulgaris and Hyssopus officinalis produced higher biomass and essential oil yield in the second year, compared to the first year.

Regardless of being native or introduced, the plants' performance is influenced by the environment. Plants vary genetically in growth patterns, flowering and susceptibility to insects and diseases. Morphological and genetic variations in Thymus species and also thyme accessions have been reported in some studies (Ma et al., 2009; Javadi et al., 2012; Moradi et al., 2014). Species with more flowers per inflorescence, more and longer inflorescences, larger flowers, longer flowering period, higher area coverage and early flowering in spring could be valuable candidates to substitute other exotic and none-native species. T. kotschyanus showed an early flowering habit, a relatively long flowering period, more inflorescences per plant, large flowers, high area coverage, long inflorescence as well as ornamental potentials. Whereas, T. serpyllum covered larger area, obtained the highest ranking score and produced more flowers and inflorescences. Its higher acceptance rate could be attributed to the light-green colour of its leaves and its creeping growing habit. Moreover, T. vulgaris had small and persistent grey-green leaves, relatively high flower number per inflorescence, inflorescence length, high aesthetics ranking and upright-growth habit. However, T. vulgaris and T. serpyllum showed smaller flowers, compared to other species. The results also showed that $T$. daenensis had such valuable characteristics as large flowers, high flower number, relatively higher area coverage, large leaves and large inflorescence diameter. Nevertheless, T. serpyllum and T. daenensis flowered very late in spring, which could be a restricting factor in regions with hot and dry summers. The other two species
(T. fedtschenkoi and T. pubescence) had quite large flowers, but their acceptance rate was relatively low. In spite of that, they can be used in breeding programs.

Evaluation of freezing stress. Survival rate. $100 \%$ survival rate was observed in all the examined species under harsh winter conditions of Ardabil, Iran during 2014 and 2016. In addition, 100\% of the plants subjected to $-10^{\circ} \mathrm{C}$ started to grow 30 days after the freezing treatment. However, all the plants were killed under $-30^{\circ} \mathrm{C}$ (data are not shown). The survival rate among six Thymus species subjected to $-20^{\circ} \mathrm{C}$ was statistically different $(P \leq 0.05)$. The highest and the lowest survival rates were respectively recorded for T. vulgaris and T. pubescence (Fig. 4).

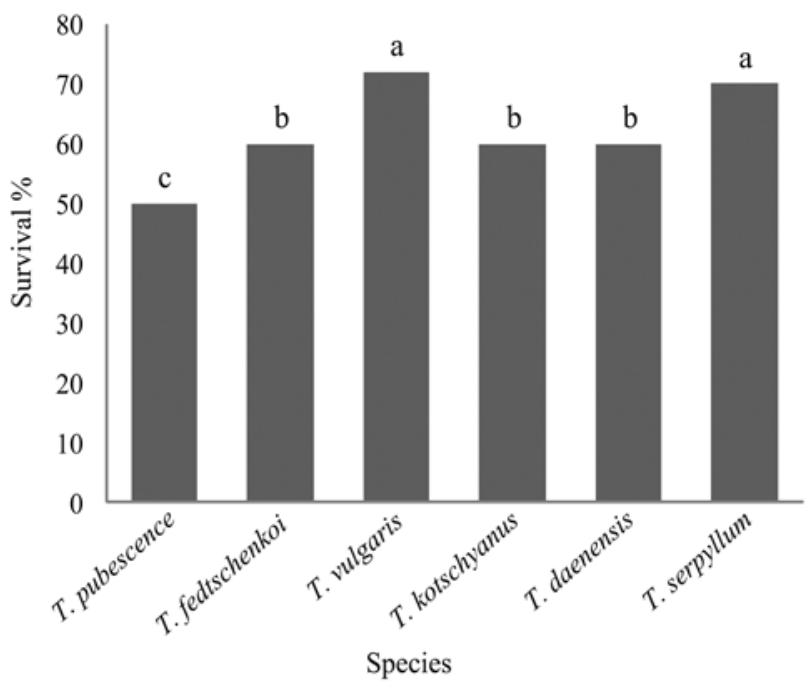

Explanation under Figure 1

Figure 4. Survival rates of different Thymus species under $-20^{\circ} \mathrm{C}$ in the freezing chamber

Beside, an average survival rate of $62 \%$ was observed in the species kept under $-20^{\circ} \mathrm{C}$ at freezing chamber conditions, which indicates the Thymus species' tolerance against the freezing stress (Table 4).

Table 4. Mean comparison of the effects of freezing temperature on the studied traits in Thymus species

\begin{tabular}{|c|c|c|c|c|c|c|}
\hline $\begin{array}{l}\text { Temperature } \\
{ }^{\circ} \mathrm{C}\end{array}$ & $\begin{array}{c}\text { Survival } \\
\%\end{array}$ & $\begin{array}{c}\text { APX } \\
\mu \mathrm{mol} \mathrm{g}^{-1} \\
\text { FW min }\end{array}$ & $\begin{array}{c}\text { SOD } \\
\mu \mathrm{mol} \mathrm{g}^{-1} \mathrm{FW} \\
\min \end{array}$ & $\begin{array}{c}\text { POD } \\
\mu \mathrm{mol} \mathrm{g}^{-1} \mathrm{FW} \\
\min \end{array}$ & $\begin{array}{c}\text { Proline } \\
\mu \mathrm{mol} \mathrm{g}{ }^{-1} \mathrm{FW}\end{array}$ & $\begin{array}{c}\text { EL } \\
\%\end{array}$ \\
\hline-10 & $100 \mathrm{a}$ & $4.9 \mathrm{~b}$ & $5.5 \mathrm{c}$ & $7.4 \mathrm{ab}$ & $0.86 \mathrm{c}$ & $25 \mathrm{c}$ \\
\hline-20 & $62 \mathrm{~b}$ & $7.83 \mathrm{a}$ & $9 \mathrm{~b}$ & $8.7 \mathrm{a}$ & $2 \mathrm{a}$ & $36 \mathrm{~b}$ \\
\hline-30 & $0 \mathrm{c}$ & $7.22 \mathrm{a}$ & $20.2 \mathrm{a}$ & $6.15 \mathrm{~b}$ & $1.72 \mathrm{~b}$ & $54.7 \mathrm{a}$ \\
\hline
\end{tabular}

Note. APX - ascorbate peroxidase, POD - peroxidase, SOD - superoxide dismutase, EL - electrolyte leakage; FW - fresh weight; different letters in columns denote significant differences between treatments (Duncan test, $p<0.05$ ). 
Electrolyte leakage. By increasing the freezing stress severity, electrolyte leakage from the leaf's cell membrane dramatically increased. Ion leakage also increased by about $29 \%$ when the temperature was lowered from $-10^{\circ} \mathrm{C}$ to $-30^{\circ} \mathrm{C}$ (Table 4). However, between -10 and $-30^{\circ} \mathrm{C}$, a small change was noticed in the electrolyte leakage of T. vulgaris. The lowest ion leakages were recorded in T. vulgaris, T. serpyllum and T. daenensis, respectively (Fig. 5).

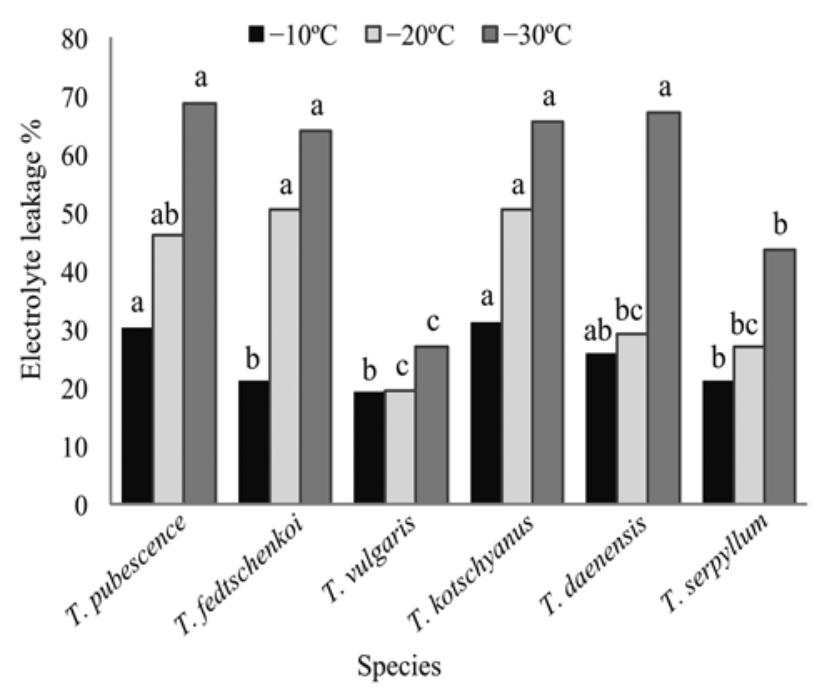

Explanation under Figure 1

Figure 5. Mean comparison of electrolyte leakage in Thymus species under freezing temperatures of $-10,-20$ and $-30^{\circ} \mathrm{C}$

This means that these species might survive better than other species when exposed to freezing stress. There was also a significant negative correlation between the survival rate and electrolyte leakage. Species with high electrolyte leakage showed low survival rate. Cell membranes are one of the first targets of many plant stresses and it is generally accepted that the maintenance of their integrity and stability under stress conditions is a major component of stress tolerance in plants. The degree of cell membrane injury induced by an abiotic stress is easily estimated by measuring the cells' electrolyte leakage. Measurement of electrolyte leakage is one of the most frequently used methods to assess plant tolerance in response to drought and low temperature (Davik et al., 2013). Nunes and Ray Smith (2003) reported that the electrolyte leakage (EL) test performed on young leaves at $-14^{\circ} \mathrm{C}$ temperature for $60 \mathrm{~min}$ proved to be the most efficient means for detecting both acclimation and cultivar differences in rose clover freezing tolerance. There are many studies in which the electrolyte leakage has been suggested to be used for ranking stress tolerance of such plant species as Prunus, Fragaria (Rugienius et al., 2016) and date palm (Al Busaidi, Farag, 2015).

Proline content. The proline content of leaves in all the species increased by lowering the temperature to $-20^{\circ} \mathrm{C}$; however, there was a decline in the proline content of the plants exposed to $-30^{\circ} \mathrm{C}$. The lowest proline contents in plants exposed to $-10^{\circ} \mathrm{C}$ were respectively observed in T. pubescence and T. serpyllum, and other species showed similar values. Under moderate freezing stress $\left(-20^{\circ} \mathrm{C}\right)$, the proline content of T. kotschyanus was higher than other species. Under severe freezing stress $\left(-30^{\circ} \mathrm{C}\right)$, the lowest proline content was seen in T. pubescence, while T. fedtschenkoi, T. kotschyanus and $T$. serpyllum showed relatively higher proline contents, compared to other three species (Fig. 6). Plants generally respond to a variety of stresses by accumulating certain

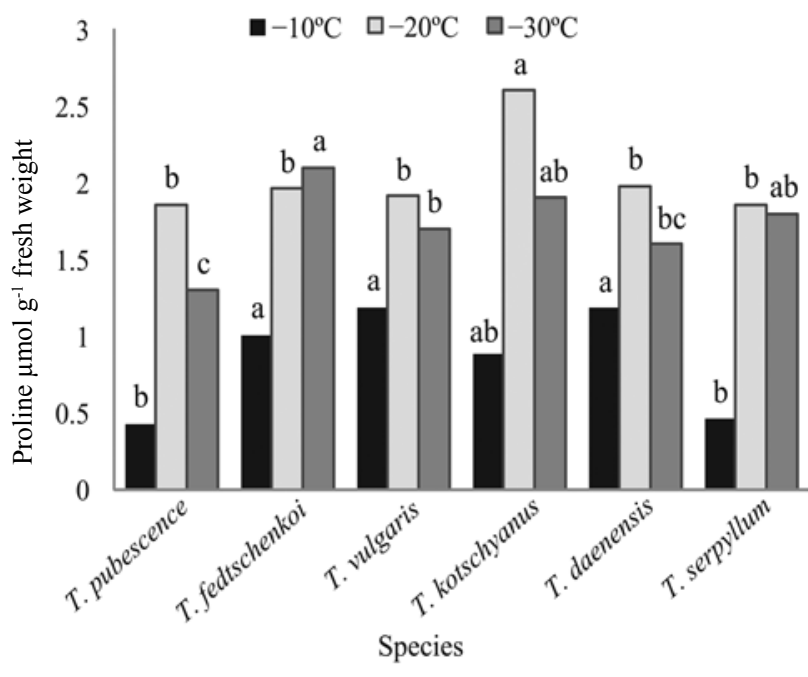

Explanation under Figure 1

Figure 6. Mean comparison of leaf proline content in Thymus species under freezing temperatures of $-10,-20$ and $-30^{\circ} \mathrm{C}$

specific metabolites, the most conspicuous of which is the proline content (Perveen et al., 2013).

Enzyme activities. According to the results, SOD activity increased by lowering the temperature from -10 to $-30^{\circ} \mathrm{C}$. The activity of POD and APX increased by increasing the stress severity (from -10 to $-20^{\circ} \mathrm{C}$ ) but decreased at $-30^{\circ} \mathrm{C}$ (Fig. 7). Despite dramatic changes in SOD and APX activity, no significant difference was observed in the enzyme activities of thyme species. However, T. serpyllum and T. vulgaris showed low POD activity, compared to other species, and their POD activity did not change by increasing the stress severity.

Species with high survival rate and low electrolyte leakage showed a lower POD enzyme activity that undermines its capability as being a good index to test the freezing tolerance of the thyme species. The findings also showed that there is a significant negative correlation between POD and SOD enzyme activity and the survival rate (Table 5). The negative correlation might be due to increasing rate of reactive oxygen species (ROS), scavenged by other antioxidant enzymes as well as the increased $\mathrm{H}_{2} \mathrm{O}_{2}$ due to SOD inactivation (Azooz et al., 2012).

Plants have been evolved with a complex antioxidant system to mitigate and repair the damage caused by ROS. The activities of antioxidant enzymes such as SOD, POD and APX are considered as a general adaptation strategy to overcome oxidative stress (Foyer, 


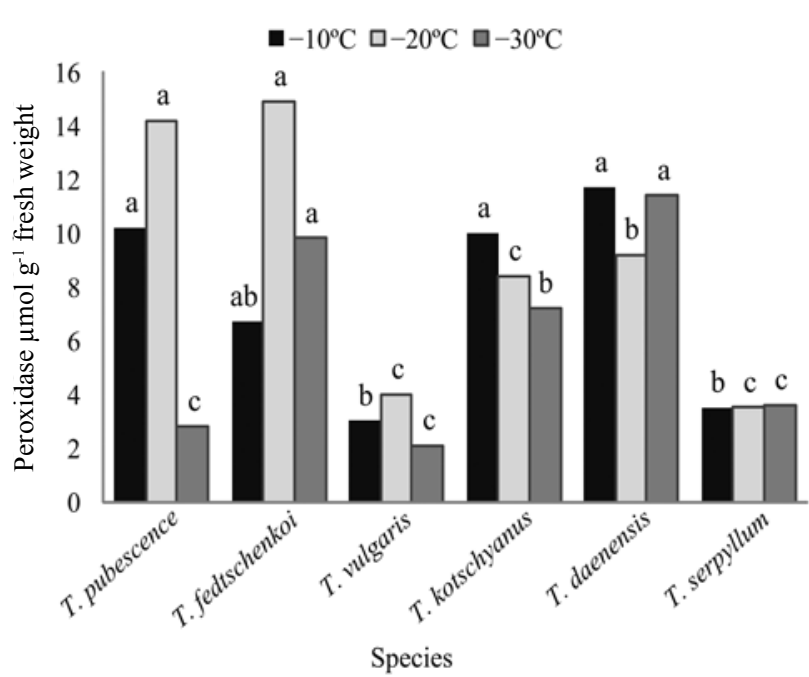

Explanation under Figure 1

Figure 7. Mean comparison of peroxidase activity in Thymus species under freezing temperatures of $-10,-20$ and $-30^{\circ} \mathrm{C}$
Noctor, 2003). The results of the present experiment showed a significant enhanced SOD activity in seedlings exposed to freezing stress. Increase in SOD activity may be attributed to the increased production of active oxygen species as a substrate that lead to increased expression of genes encoding SOD. The present study shows a significant increase in POD activity of Thymus species under moderate freezing stress and a decline under severe freezing stress. The reduction of POD activity might be due to the inhibition of enzyme synthesis or change in the assembly of enzyme subunits under stress conditions (Abedi, Pakniyat, 2010). Decreased enzyme activity has been reported under low temperature (Asadi-Sanam et al., 2015), insecticide stress (Bashir et al., 2007) and drought (Abedi, Pakniyat, 2010). The higher activity of POD, SOD and APX under freezing conditions is a sound indication of Thymus species ability to cope with ROS. Therefore, it could be suggested that the increase noticed in the activities of antioxidant enzymes is attributed to the adaptive defence system of these species against the freezing stress.

Table 5. Pearson's correlation coefficient between variables under the freezing chamber condition

\begin{tabular}{ccccccc}
\hline & EL & Proline & SOD & POD & APX & Survival \\
\hline EL & 1 & & & & & \\
Proline & $0.3^{* *}$ & 1 & & & & \\
SOD & $-0.63^{* *}$ & $0.41^{* *}$ & 1 & & & \\
POD & $0.35^{* *}$ & $0.57^{* *}$ & $0.41^{* *}$ & 1 & 1 & 1 \\
APX & $0.35^{* *}$ & $0.11 \mathrm{~ns}$ & $0.07 \mathrm{~ns}$ & $0.13 \mathrm{~ns}$ & 0.01 & $-0.47^{* *}$ \\
Survival & $-0.68^{* *}$ & $0.5^{* *}$ & $-0.9^{* *}$ & & & \\
\hline
\end{tabular}

EL - electrolyte leakage, SOD - superoxide dismutase, POD - peroxidase, APX - ascorbate peroxidase; ** - significant at the 0.01 level, ns - not significant

\section{Conclusion}

The study showed that it is possible to use all of the investigated six thyme (Thymus L.) species as ground-covering plants because of their sufficiently high ornamental potential and tolerance to freezing stress. However, T. kotschyanus, T. serpyllum and T. vulgaris with good ornamental potential and also higher freezing stress tolerance are better candidates than $T$. daenensis T. fedtschenkoi and T. pubescence for being used in landscaping plans.

Received 02062017 Accepted 14112017

\section{References}

1. Abedi T., Pakniyat H. 2010. Antioxidant enzyme changes in response to drought stress in ten cultivars of oilseed rape (Brassica napus L.). Czech Journal Genetic and Plant Breeding, 46 (1): 27-34.

2. Acar C., Var M. 2001. A study on the adaptations of some natural ground cover plants and on their implications for landscape architecture in the ecological conditions of Trabzon. Turkish Journal of Agriculture and Forestry, 25: 235-245 (in Turkish).
3. Al Busaidi K. T. V. S., Farag K. M. 2015. The use of electrolyte leakage procedure in assessing heat and salt tolerance of Ruzaiz date palm (Phoenix dactylifera L.) cultivar regenerated from tissue culture and offshoot and treatments to alleviate the stressful injury. Journal of Horticulture and Forestry, 7 (4): 104-111.

https://doi.org/10.5897/JHF2014.0378

4. Armonienè R., Liatukas Z., Brazauskas G. 2013. Evaluation of freezing tolerance of winter wheat (Triticum aestivum L.) under controlled conditions and in the field. ZemdirbysteAgriculture, 100 (4): 417-424.

https://doi.org/10.13080/z-a.2013.100.053

5. Asadi-Sanam S., Zavareh M., Pirdashti H., Sefidkon F., Nematzadeh G. 2015. The physiological and biochemical responses of Eastern purple coneflower to freezing stress. Russian Journal of Plant Physiology, 62 (4): 515-523. https://doi.org/10.1134/S1021443715040056

6. Asgarzadeh M., Vahdati K., Lotfi M., Arab M., Babaei A., Naderi F., Pir Soufi M., Rouhani G. 2014. Plant selection method for urban landscapes of semi-arid cities (a case study of Tehran). Urban Forestry and Urban Greening, 13 (3): $450-458$. https://doi.org/10.1016/j.ufug.2014.04.006

7. Azooz M. M., Abou-Elhamd M. F., Al-Fredan M. A. 2012. Biphasic effect of copper on growth, proline, lipid peroxidation and antioxidant enzyme activities of wheat (Triticum aestivum cv. Hasaawi) at early growing stage. Australian Journal of Crop Science, 6 (4): 688-694. 
8. Bashir F., Siddiqi T., Mahmooduzzafar O., Iqbal M. 2007. The antioxidative response system in Glycine $\max (\mathrm{L}$.) Merr. exposed to deltamethrin, a synthetic pyrethroid insecticide. Environmental Pollution, 147 (1): 94-100. https://doi.org/10.1016/j.envpol.2006.08.013

9. Bates L. S., Waldren R. P., Teare I. D. 1973. Rapid determination of free proline for water stress study. Plant and Soil, 39: 205-207. https://doi.org/10.1007/BF00018060

10. Brzuszek R. F., Harkess R. L., Mulley S. J. 2007. Landscape architects' use of native plants in the southeastern United States. HortTechnology, 17 (1): 78-81.

11. Cavender-Bares J. 2007. Chilling and freezing stress in live oaks (Quercus section Virentes): intra- and interspecific variation in PS II sensitivity corresponds to latitude of origin. Photosynthesis Research, 94 (2-3): 437-453. https://doi.org/10.1007/s11120-007-9215-8

12. Chaudhary P., Godara S., Cheeran A. N., Chaudhari A. K. 2012. A fast and accurate method for leaf area measurement. International Journal of Computer Applications, 49 (9): 22-25.

https://doi.org/10.5120/7655-0757

13. Davik J., Koehler G., From B., Torp T., Rohloff J., Eidem P., Wilson R. C., Sønsteby A., Randall S. K., Alsheikh M. 2013. Dehydrin, alcohol dehydrogenase, and central metabolite levels are associated with cold tolerance in diploid strawberry (Fragaria spp.). Planta, 237 (1): 265-277. https://doi.org/10.1007/s00425-012-1771-2

14. Domenghini J. C. 2012. Water use and drought resistance of turfgrass and ornamental landscape plant species: $\mathrm{PhD}$ thesis. Kansas State University, USA, 101 p.

15. Fabbri L. T., Ploschuk E. L., López M. V., Insausti P., Rua G. H. 2015. Freeze tolerance differs between two ecotypes of Paspalum vaginatum. Acta Botanica Brasilica, 30 (1): 152-156.

https://doi.org/10.1590/0102-33062015abb0233

16. Foo C. L. 2012. Ground cover plants for weed control in amenity horticulture: doctoral dissertation. Massey University of New Zealand, $228 \mathrm{p}$.

17. Foyer C. H., Noctor G. 2003. Redox sensing and signalling associated with reactive oxygen in chloroplasts, peroxisomes and mitochondria. Physiologia Plantarum, 119: 355-364. https://doi.org/10.1034/j.1399-3054.2003.00223.x

18. Ghani A., Tehranifar A., Shooshtarian S., Boghrati M. 2011. Comparative study of the ornamental potential of six Achillea species from Iran. Sought Western Journal of Horticulture, Biology and Environment, 2 (2): 139-155.

19. Giannopolitis C. N., Ries S. K. 1977. Superoxide dismutases: I. Occurrence in higher plants. Plant Physiology, 59 (2): 309-314. https://doi.org/10.1104/pp.59.2.309

20. Hao W., Arora R., Yadav A. K., Joshee N. 2009. Freezing tolerance and cold acclimation in guava (Psidium guajava L.). HortScience, 44 (5): 1258-1266.

21. In B. C., Motomura S., Inamoto K., Doi M., Mori G. 2007. Multivariate analysis of relations between preharvest environmental factors, postharvest morphological and physiological factors and vase life of cut Asami Red roses. Journal of the Japanese Society for Horticultural Science, 76 (1): 66-72. https://doi.org/10.2503/jjshs.76.66

22. Javadi H., Hesamzadeh Hejazi S. M., Babayev M. Sh. 2012. Chromosome reports on two species of Thymus (Lamiaceae). Iranian Journal of Botany, 18 (1): 108-111.
23. Khazaie H. R., Nadjafi F., Bannayan M. 2008. Effects of irrigation frequency and planting density on herbage biomass and oil production of thyme (Thymus vulgaris) and hyssop (Hyssopus officinalis). Industrial Crops and Products, 27 (3): 315-321. https://doi.org/10.1016/j.indcrop.2007.11.007

24. Li R., Qu R., Bruneau A. H., Livingston D. P. 2010. Selection for freezing tolerance in St. Augustine grass through somaclonal variation and germplasm evaluation. Plant Breeding, 129 (4): 417-421.

25. Livingston D. P., Premakumar R., Tallury S. P. 2006. Carbohydrate partitioning between upper and lower regions of the crown in oat and rye during cold acclimation and freezing. Cryobiology, 52: 200-208. https://doi.org/10.1016/j.cryobiol.2005.11.001

26. Ma L., Y., Yao L., Wu Y. 2009. ISSR analysis of genetic relationships between seven varieties of thyme. Journal of Shanghai Jiaotong University (Agricultural Science), 27 (3): 219-222 (in Chinese).

27. Moradi M., Nazeri V., Hassandokht M. R., Soorni A. 2014. Evaluation morphological diversity and essential oil content of Thymus transcaspicus Klokov. in Iran. International Journal of Farming and Allied Sciences, 3 (10): 1109-1116.

28. Mugge F. L. B., Paula-Souza J., Melo J. C., Brandao M. G. L. 2016. Native plant species with the economic value from Minas Gerais and Goiás: a discussion on the currentness of the data recovered by the French naturalist Auguste de Saint-Hilaire. Horticultura Brasileira, 34 (4): 455-462. https://doi.org/10.1590/s0102-053620160402

29. Nakano Y., Asada K. 1981. Hydrogen peroxide is scavenged by ascorbate-specific peroxidase in spinach chloroplasts. Plant and Cell Physiology, 22 (5): 867-880.

30. Nunes M. E. S., Ray Smith G. 2003. Electrolyte leakage assay capable of quantifying freezing resistance in rose clover. Crop Science, 43 (4): 1349-1357. https://doi.org/10.2135/cropsci2003.1349

31. Perveen S., Shinwari K. I., Jan M., Malook I., Rehman S., Khan M. A., Jamil M. 2013. Low temperature stress induced changes in biochemical parameters, protein banding pattern and expression of zat 12 and $m y b$ genes in rice seedling. Journal of Stress Physiology and Biochemistry, 9 (4): 193-206.

32. Pirbaluti A. G., Bistgahi Z. E., Malekpour F. 2015. An overview on genus Thymus. Journal of Herbal Drug, 6(2): 93-100.

33. Roloff A., Korn S., Gillner S. 2009. The climate-speciesmatrix to select tree species for urban habitats considering climate change. Urban Forestry and Urban Greening, $8(4): 295-308$. https://doi.org/10.1016/j.ufug.2009.08.002

34. Rowland L. J., Ogden E. L. 2013. Variation among high bush blueberry cultivars for frost tolerance of open flowers. HortScience, 48 (6): 692-695.

35. Rugienius R., Šnipaitienè L., Stanienė G., Šikšnianienė J. B., Haimi P., Baniulis D., Frercks B., Pranckietis V., Lukoševičiūtė V., Stanys V. 2016. Cold acclimation efficiency of different Prunus and Fragaria species and cultivars in vitro. Zemdirbyste-Agriculture, 103 (2): 207-214. https://doi.org/10.13080/z-a.2016.103.027

36. Tallamy D. W. 2007. Bringing nature home: how you can sustain wildlife with native plants, $360 \mathrm{p}$. 
ISSN 1392-3196 / e-ISSN 2335-8947

Zemdirbyste-Agriculture, vol. 105, No. 1 (2018), p. 79-88

DOI $10.13080 / \mathrm{z}-\mathrm{a} .2018 .105 .011$

\title{
Šešių rūšiụ čiobrelių, skirtų vietovèms apželdinti, dekoratyvumo potencialas ir atsparumas šalčiui
}

\author{
H. M. Lajayer ${ }^{1,2}$, H. Zakizadeh ${ }^{1}$, Y. Hamidoghli ${ }^{1}$, M. H. Bigluei ${ }^{1}$, E. Chamani ${ }^{2}$ \\ ${ }^{1}$ Guilan universitetas, Iranas \\ ${ }^{2}$ Mohaghegh Ardabili universitetas, Iranas
}

\section{Santrauka}

Tyrimo metu analizuota galimybè vietovėms apželdinti panaudoti tris vietines (Thymus kotschyanus Boiss. Hohen, T. fedtschenkoi Ronniger bei T. pubescence Boiss \& Kotschy ex Celak), vieną endeminę (T. daenensis Jalas) ir dvi dažnai aptinkamas (T. serpyllum L. bei T. vulgaris L.) čiobrelio (Thymus spp.) rūšis. Šių rūšių dekoratyvumo potencialas ir atsparumas šalčiui buvo vertinta dvejus (2014-2015 ir 2015-2016) metus. Lyginant su kitomis rūšimis, T. kotschyanus išsiskyre šiomis dekoratyvumo savybėmis: ankstyvu ir ilgu žydejjimu, gausiu kiekiu žiedynų su dideliais žiedais, gana dideliu ploto dengimu ir aukštu vizualaus vertinimo balu. T. serpyllum pasižymėjo didesniu žiedynų ir žiedų skaičiumi žiedyne, ilgesniais žiedynais, dideliu ploto dengimu ir aukštu vizualaus vertinimo balu. Augalai, šaldymo kameroje veikiami -10 ir $-30^{\circ} \mathrm{C}$ temperatūros, pademonstravo 100 ir $0 \%$ išgyvenamumą, o esant $-20^{\circ} \mathrm{C}$ temperatūrai daugiausia išgyveno T. vulgaris ir T. serpyllum rūšių augalų. Buvo nustatytas visų rūšių augalų šimtaprocentinis išgyvenamumas atšiaurios žiemos sąlygomis. Elektrolitų nuotėkio matavimas parodè didesni T. serpyllum, T. kotschyanus ir T. vulgaris atsparumą šalčiui, palyginus su kitų tirtų rūšių čiobreliais. Be to, T. vulgaris ir T. kotschyanus rūšių augaluose buvo nustatyti didžiausi kiekiai prolino. Reaguojant i šalčio stresą oksidacinio fermento peroksidazės aktyvumas T. vulgaris ir T. serpyllum rūšių augaluose nepakito, o T. kotschyanus augaluose sumažèjo didinant streso lygị. Tarp tirtų rūšiu nenustatyta superoksido dismutazès ir askorbato peroksidazės fermentų aktyvumo esminių skirtumų. Visos tirtosios rūšys pademonstravo vertingas dekoratyvumo savybes ir atsparumą šalčio stresui, tačiau kraštovaizdžio apželdinimo programoms buvo pasiūlytos tik T. kotschyanus, T. serpyllum ir T. vulgaris.

Reikšminiai žodžiai: čiobrelis, elektrolitų nuotėkis, peroksidazè, vietiniai augalai, žiedų skaičius, žydẻjimo laikotarpis. 